\title{
THE IMPACT OF STAFF WELFARE ON JOB COMMITMENT IN TUYIL PHARMACEUTICAL COMPANY, ILORIN, KWARA STATE
}

\author{
JIMOH,Adams Lukman ${ }^{1}$, KADIRI, Ismaila Bolarinwa Ph.D ${ }^{2}$. \\ Department of IRPM, Faculty of Management Sciences,University of Ilorin, Ilorin, Nigeria. ${ }^{1,2}$ \\ jimohadamslukman@gmail.com¹, bolakadiri@yahoo.com ${ }^{2}$ \\ DOI: 10.36108/ljerhrm/8102.01.0120
}

\begin{abstract}
A very few organizations believe that the employees of their organizations are the main assets which can lead them to success or failure. Unless and until the employees of these organizations are satisfied, motivated, encouraged, none of the organizations can progress or achieve success. This research was carried out with the objective of examining the impact of staff welfare on job commitment in Tuyil pharmaceutical company, Ilorin, Kwara State. Data for the study were collected from both primary and secondary sources. A descriptive research approach was used. The population for the study was 255 staff of Tuyil Pharmaceutical company. About 72 respondents which served as the study sample size was determined through Guilford formula. The study used structured questionnaire to elicit information from the respondents. The data collected were analyzed through the use ofLeast square regression. The result of the findings revealed that $\left(r=.890, r^{2}=.792, p=0.5\right)$ meaning that staff welfare enhances job commitment. Therefore, the study concludes that employee welfare have significant impact on job commitment. The study recommends that management should put more attention on the welfare facilities that improve the job commitment so as to achieve improve employee satisfaction and commitment in the organization.
\end{abstract}

Keywords: employee welfare, job commitment, retention and employee satisfaction

\section{Introduction}

Welfare is a corporate attitude or commitment reflected in the expressed care for employees at all levels, underpinning their work and the environment in which it is performed (Cowling \& Mailer, 1992). Specifically, adequateemployee welfare helps to motivate staff or employees and ensure increased productivity and more profit for the organization.Job commitment is the feeling of responsibility that a person has towards the mission and goals of an organization. Job commitment is also a situation in which individual or group of individuals devote their time to work in an organization. When an individual has job commitment, he or she is more likely to perform tasks and responsibilities that will help an organization achieve its goal.

Most organizations achieve remarkable success in their operations not only because they operate in good environments, or because they are capable of competing favorably with other organizations but mostly because the management of such organizations provides them with the incentives that make their work worth enjoying.A committed worker will always put his best effort to ensure the realization of the organizational goals. In view of this, Porter and Smith (1970) believed that job commitment largely involves a desire to continue one's membership of a particular organization, readiness to exert high level of effort on behalf of the organization and an acceptance of the goals and values of the organization. As a result, many organizations have shown interest in ensuring that their employees are highly motivated through the giving of welfare benefits to guarantee positive behaviour or strong commitment.

\subsection{Statement of the Problem}

The satisfaction and commitment that workers derive from their employment is largely dependent on how the benefit given to them meet their needs. Thus, they can only be substantially productive when they perceive that there is positive correlation between their productivity and kind of welfare benefit given to them.Therefore, workers' welfare benefits are important in business organization for the achievement of its objectives in such areas as materials and personnel development, job satisfaction and rate of turnover. A very few organizations believe that the employees of their organization are its main assets which can lead them to success or failure. Unless and until the employees of these organizations are satisfied, motivated and encouraged, none of the organization can progress or achieve success. This study therefore sets out to look into the impact of staff welfare on employees' job commitment using Tuyil Pharmaceutical Company as a case study.

\section{Literature Review}

Concept ofStaff Welfare

Staff welfare refers to the various services, benefits and facilities offered by the employer to employees with a purpose of enriching the life of employees and to keep them happy and contented (Mishra \& Manju, 2007).Welfare includes anything that is done for the comfort and improvement of employees and is provided over 
and above the wages. Welfare helps in keeping the morale and motivation of the employees high so as to retain the employees for longer duration. The welfare measures need not be in monetary terms only but in any kind or forms. Employee's welfare includes monitoring of working conditions, creation of industrial harmony through infrastructure for health, industrial relations and insurance against disease, accident and unemployment for the workers and their families. Staff welfare entails all those activities of employer which are directed towards providing the employees with certain facilities and services in addition to wages or salaries.

\section{Classification of Staff Welfare}

Organizations provide welfare facilities to their employees to keep their motivation levels high. The staff welfare schemes can be classified into two categories: Statutory and Non-Statutory labour welfare and Intra-mural and Extra-mural labour welfare. Statutory Labour Welfare comprises of provisions on welfare activities, which depends on coercive power of the government for its implementation. The government enacts certain legislation for labour welfare to be enforced to achieve the minimum standards of safety and healthy working conditions for workers(Mishra \& Manju, 2007). The industrial unit is required by law to fulfill their statutory obligations on labour welfare.Non-Statutory Welfare comprises all those welfare activities which industrial units undertake for the welfare of their workers on a voluntary basis in addition to statutory labour welfare measures.

The non-statutory welfare includes housing, education, recreation, subsidized loan and other such facilities that are voluntary in nature.Intra-Mural Welfare Facilitiesare those which are provided within the premises of the industrial establishment such as crèches, washing and bathing facilities, latrines and urinal, rest rooms and canteens, facility of drinking water, facility for deterrence arrangement with factor to take care of welfare activities, occupational safety, protective uniforms, and shift allowance.Extra-Mural Welfare Facilities are labour facilities which are provided outside the premises of industrial establishment such as social insurance(gratuity, pension etc.), maternity benefit, sport facilities, cultural activities, holiday homes, library and reading rooms, housing facilities, vocational training, education facilities, health and medical facilities, leave travel facilities, fair price shops, workers co-operatives including stores, co-operatives including co-operative credit societies, vocational training for dependent of workers, other programes for the welfare of women, youth and children and transport facility to and from the place of work. These are established by ILO in 1963.

\section{Principles of Staff Welfare}

Every effort should be made to give workers some voice in the choice of welfare activities so include long as it does not amount to dictation from workers.Staff welfare depends on certain basic principles, which includes: adequacy of wages, impact of efficiency, increase in personality and totality of welfare.

\section{Theoretical Clarification}

There are various theoretical explanation advocated which may encourage the employers to introduce different labour welfare activities. The model below help to give a clear illustration of these theories.

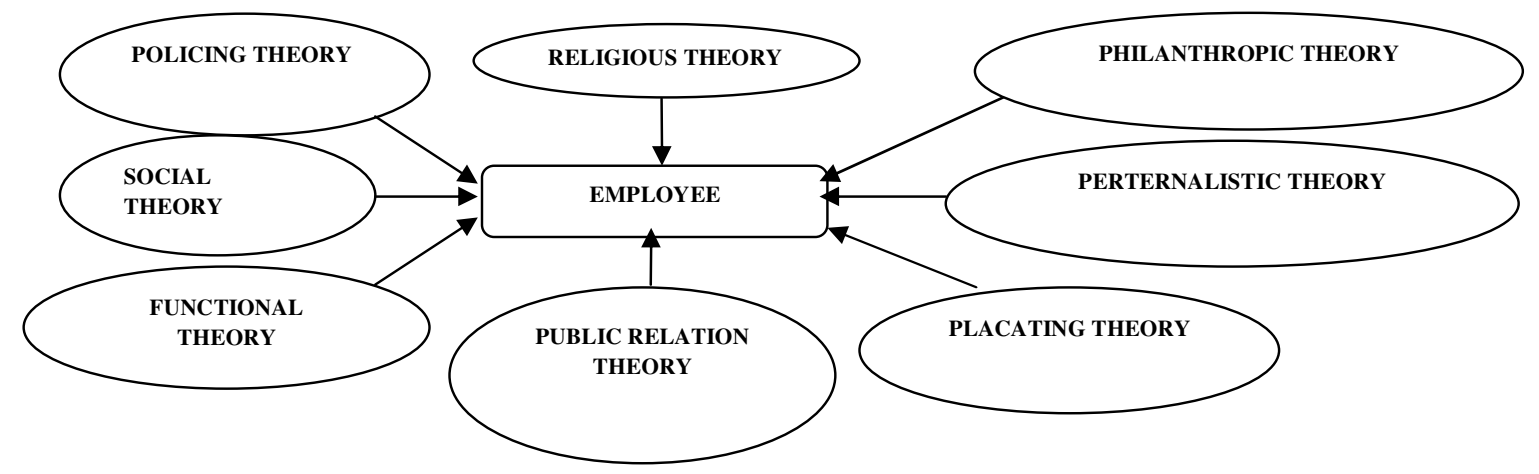

SOURCE: Aswathappa. Human Resource Management,Test and cases, 2008.

\section{- Religious Theory}

The religion theory constitutes elements such as investment and atonement for welfare of workers. Concept of investment implies that the benefits of today's work will be reaped tomorrow. It is also widely believed that because of this belief many companies provide facilities such as canteens and crèches. The atonement aspect of the religion theory implies that the present disabilities of a person's good deeds now compensate for his/her sin. Therefore, employers provide benefits and facilities to workers for their sin. Welfare activities are considered to 
be an effort to appeal to the religious value of the owner of the firm by suggesting that welfare act can purify him from his sinful activities of exploitation and profit making. Sharing wealth and acting for welfare class is part of religious duty of every employer.

- Philanthropic Theory

Philanthropic theory means affection for mankind. The philanthropic theory of labour welfare refers to the provision of good working condition, facilities such as rest room and canteens to show kindness in order to improve the working condition for workers. These theory further emphases that every member of the industrial system should have harmonious relations with the rest of the stakeholders. It is the duty and responsibility of the wealthy people to help the underprivileged (Mishra \& Bhagat,2010).

\section{- Paternalistic Theory}

This theory is also called Trusteeship theory. This implies that it is the duty of the owner to share the wealth and use it wisely for the larger interest of workers who equally contributed in the production of the wealth.

\section{- Policing Theory}

According to this theory, welfare is a legal or statutory responsibility of the employer. Under this theory every employer is compelled to provide minimum comforts to their employee such as minimum security provisions, minimum safety and other benefits. According to this theory, the employers exploit the workers with unjust and unfair tactics. Government take the role of policemen and enforces measures in the industrial unit or factory for requisite welfare services and provisions for punishment in case of non-compliance. This concept of legislation and its enforcement for compliance is known as the policing theory of labour welfare.

\section{- Placating Theory}

Placating theory states that management should endorse welfare measures not as charity, but as a reward efforts on the part of the worker (Kohli \& Sharma, 1997).It is the right of the labour class to organize itself into association or unions, to plan, protest activities and force the management to provide more welfare services to the workers. Therefore it is evident that the stronger the labour class, the greater the welfare services to be conceded for the workers. The labour unions are those that compel management to satisfy the worker's needs.

\section{- Efficiency/Functional Theory}

According to functional theory, welfare measures are to be provided on the grounds of efficiency and productivity (Mishra \& Bhagat, 2010). This implies that the facilities and benefits are being provided to workers to make them more efficient and productive. There is an effort going on to correlate labor welfare facilities and resultant increase in the efficiency of the workers. It is debated that introduction of welfare promoting activities do pay rich dividends in terms of higher productivity.

\section{- Public Relations Theory}

According to Public Relations theory, welfare facilities are provided to create goodwill and generate a good image on the minds of workers and the society. In other words, Public Relations theory says that welfare are meant to create a good impression on the workers and the public.

\section{- Social Theory}

This implies that an industrial establishment is morally bound to provide decent working condition for the employees in addition to improve environment and condition of the society.labour welfare should progressively develop into social welfare. It is evident with theoretical explanation on labour welfare practices and its evolution over the years that none of the single theory can explain the dynamic nature and variety of welfare measures that can be provided to working class for their development and decent living.

\section{Empirical Review}

Victor (2014) examined staff motivation and job satisfaction among the junior staff of Cross River University of Technology (CRUTECH), Calabar, Cross River State Nigeria. Two research hypotheses were formulated to guide this study. A staff motivation and job satisfaction questionnaire (SMJSQ) was constructed and used for data collection. This instrument, with twenty (20) items, was administered to one hundred and sixty one (161) junior staff from the three campuses that make up the university, using the stratified random sampling technique. The Pearson Product Moment correlation analysis was used to test the hypotheses. From the findings, it was realized that staff welfare and participatory decision making are all significantly related to job satisfaction.

Irefin and Mechanic (2014)examined the effect of employee commitment on organizational performance with special interest in Coca Cola Nigeria Limited in Maiduguri.A total of one hundred (120) respondents were selected for the survey. The sampling technique used was stratified random sampling. Data were obtained from respondents from each cadre of the organizational structure.Both descriptive and explanatory research 
methodologies were adopted in the study. A five point numerically scaled Likert-Type questionnaire was constructed and administered among selected Staff. The research hypotheses were tested using the Pearson Correlation Coefficient. The result shows that: the level of employee commitment of Staff of Coca Cola Company Plc is very high; there is a fairly high relationship between employee commitment and organizational performance.

Lagat, Mutai and Kosgey (2014), examined the importance of employee welfare and performance a case study of the Universities' Academic Staff Union in Kenya. A representative group of 82 respondents was obtained by simple random sampling from a sample frame of the 435 general members of the UASU. The results indicated that the UASU had different but positive impacts on the variables affecting employee welfare and, consequently, employee performance.

\section{Methodology}

\section{Population of the Study and Sample Size}

The population for this research study is 255.The sample frame for this study comprised of staff of Tuyil Pharmaceutical Company. The sample size has been determined by adopting Guilford formula.

\section{$\frac{N}{1+Q^{2} N}$}

Where N=Population Size

$$
\begin{aligned}
\mathrm{Q}=\text { alpha } & =0.10 \\
N=\frac{255}{1+(0.10)^{2}(255)} & =72
\end{aligned}
$$

To ensure proper analysis and interpretation of the data to address the problems stated, questions, objectives and hypotheses, each of the stated hypotheses will be tested statistically using regression and correlation. Regression can be defined as the study of relationship between two or more variables. The aim is to discover the nature of the relationship between variables, measure it and make prediction about the value of one variable from given values of the other. Descriptive analysis describes conditions, population and phenomena as they are. This was done using the Statistical Package for Social Science (SPSS).

Hypothesis:Good staff scheme welfare does not have positive impact on staff performance in an organization.

\section{Model Summary}

\begin{tabular}{|l|r|r|r|c|}
\hline Model & \multicolumn{1}{|c|}{$\mathrm{R}$} & R Square & Adjusted R Square & Std. Error of the Estimate \\
\hline 1 & $.890^{\mathrm{a}}$ & .792 & .779 & .62578 \\
\hline
\end{tabular}

a. Predictors: (Constant), Retirement benefit, Bonus payment, Medical reimbursement,

\begin{tabular}{|c|c|c|c|c|c|}
\hline Model & Sum of Squares & Df & Mean Square & $\mathrm{F}$ & Sig. \\
\hline $\begin{array}{r}\text { Regression } \\
\text { Residual } \\
\\
\text { Total }\end{array}$ & $\begin{array}{l}99.638 \\
26.237 \\
125.875\end{array}$ & $\begin{array}{l}4 \\
67 \\
71\end{array}$ & $\begin{array}{r}24.909 \\
.392\end{array}$ & 63.610 & $.000^{\mathrm{a}}$ \\
\hline
\end{tabular}
Promptly paid salaries.

a. Predictors: (Constant), Retirement Benefit, Bonus payment, medical Reimbursement, Promptly paid salaries

b. Dependent Variable: employee commitment. 


\begin{tabular}{|c|c|c|c|c|c|c|}
\hline \multicolumn{7}{|c|}{ Coefficients $^{\mathrm{a}}$} \\
\hline \multirow{2}{*}{\multicolumn{2}{|c|}{ Model }} & \multicolumn{2}{|c|}{$\begin{array}{l}\text { Unstandardized } \\
\text { Coefficients }\end{array}$} & \multirow{2}{*}{$\begin{array}{c}\begin{array}{c}\text { Standardized } \\
\text { Coefficients }\end{array} \\
\text { Beta }\end{array}$} & \multirow[b]{2}{*}{$\mathrm{T}$} & \multirow[b]{2}{*}{$\mathrm{Sg}$. } \\
\hline & & B & Std. Error & & & \\
\hline \multirow[t]{5}{*}{1} & (Constant) & .198 & .225 & & .879 & .383 \\
\hline & Bonus payment & .192 & .065 & .195 & 2.935 & .005 \\
\hline & $\begin{array}{l}\text { Promptly paid } \\
\text { salaries }\end{array}$ & .489 & .121 & .475 & 4.022 & .000 \\
\hline & $\begin{array}{l}\text { Medical } \\
\text { reimbursement }\end{array}$ & .154 & .098 & .158 & 1.578 & .119 \\
\hline & Retirement Benefit & .176 & .130 & .177 & 1.356 & .180 \\
\hline
\end{tabular}

a. Dependent Variable: Staff performance

Source: SPSS result, 2017

\section{Interpretation of Findings}

The coefficients of individual independent variables indicated that bonus payment (.192), promptly paid salaries (.489), medical reimbursement (.154) and retirement benefit (.176) have positive relationship with staff performance.Considering the p-value and $\{\mathrm{t}$-statistics $\}$ value of individual independent variables, Bonus payment .005 and $\{2.935\}$ and promptly paid salaries .000 and $\{4.022\}$ are significant since their respective p-values are less than alpha level of .05. It can therefore be concluded that bonus payment and promptly paid salaries as proxies of staff welfares have impact on staff performance. On the other hand, medical reimbursement .119 and \{1.578\} and Retirement benefit .180 and $\{1.356\}$ are not significant since their respective p-value is greater than alpha level of significance.

It can therefore be concluded since $\mathrm{R}^{2}$ of $79 \%$ is positive and the ANOVA significance of .000 is less than $\mathrm{p}$-value of .05 , that the null hypothesis is rejected. Hence, there is a positive impact of staff welfare on profitability in organization specifically in Tuyil Pharmaceutical Company.

\section{Conclusion}

The findings show that there is a strong positive impact of welfare packageson operation of the company.This implies that proper welfare facilities will increase the activeness and performance of employees in the organization.

\section{Recommendations}

- Organizations should also make others motivational factors available like recognition for achievement, opportunity for growth, responsibilities etc in an organization, these will motivate workers to put more effort and improve their performance.

- There should be harmony between the goals of the organization with the goals of employee through making sure that the immediate needs are recognized in the pay package or in any type of reward, with this job commitment and low labour turnover will be attained and it would also be interesting to further examine what welfare packages that will reduce the labour turnover in an organization.

\section{References}

Aswathappa, K. (2008). Human resource management. New Delhi, India: Tata McGraw Hill Education Private Limited.

Cowling, A.\& Mailer, C. (1992). Managing human resources. ( $2^{\text {nd }}$ ed). London: Edward Arnold. 
ILO (2004). World employment report, 2004-2005, retrieved Fed. 15,2014. Available: http://www.ilo.org/public/english/ employment/stra

Mishra, S.N. (2010). Labour and industrial laws. Central Law Publications, Allahabad, 837-840.

Porter,L.W., \& Smith, F.J. (1970).The etiology of organizational commitment. Unpublishedmanuscript, University of California at Irvine. 